\title{
EARNINGS QUALITY AND EARNINGS FORECASTS BASED ON A CROSS-SECTIONAL MODEL
}

Kazumasa Higashikawa

Osaka University, Japan

E-mail: tgm007hk@student.econ.osaka-u.ac.jp

\begin{abstract}
This study examined the effect of earnings quality on the performance of earnings forecasts using a cross-sectional model. Earnings quality is measured by the residuals of a regression analysis that relates working capital accruals to operating cash flows for the current, previous, and next period (SRESID), the lower the earnings quality, the larger the forecasting errors. This result holds for both bias, defined by the difference between the actual and the forecasted values, and accuracy, measured as the absolute value of bias. The relationship between earnings quality and forecasting errors does not change after controlling for other potential earnings attributes. In addition, the basic conclusion remains the same when SRESID is estimated using a time- series model, and when the look-ahead bias inherent in SRESID is removed. These findings suggest that SRESID is useful for market participants in selecting a relevant earnings forecasting model.
\end{abstract}

Keywords: earnings quality, cross-sectional forecast model, forecast bias, forecast accuracy

ARTICLE INFO

\section{Article History:}

Received: 29 April 2020

Accepted: 26 July 2020

Published: 31 December 2020 


\section{INTRODUCTION}

Since forecasting earnings is an essential task for assessing firm value (Ohlson, 2001; Frankel \& Lee, 1998) and estimating the cost of capital (Gebhardt, Lee, \& Swaminathan, 2001; Easton \& Monahan, 2005), it receives special attention from market participants. While the valuation technique per se needs to be elaborated (Penman \& Sougiannis, 1998; Gao, Myers, Myers, \& Wu, 2019), if the valuation inputs are not reliable, the accuracy of the estimated value is not warranted, regardless of the adopted techniques (Lundholm \& O'Keefe, 2001). This study empirically addressed the conditions necessary to ensure the accuracy of earnings forecasts in terms of earnings quality.

Market expectations for earnings are considered to highly depend on analyst forecasts (Brown \& Rozeff, 1978; Fried \& Givoly, 1982). Similarly, management forecasts, which are voluntarily disclosed in the United States and substantially mandated to be disclosed in Japan, are also recognized as an important source of information for market participants (Patell, 1976; Pownall, Wasley, \& Waymire, 1993). However, due to the complex incentives faced by analysts and managers, both forecasts are known to be accompanied by serious biases (Francis \& Philbrick, 1993; Lin \& McNichols, 1998; Rogers \& Stocken, 2005; Chan, Lin, Yu, \& Zhao, 2018). Specifically, cognitive bias such as manager's over-optimism also affects the accuracy of management forecasts (Hilary, Hsu, Segal, \& Wang, 2016; Hribar \& Yang, 2016; Kimbrough, Lee, \& Zheng, 2020).

Recently, earnings forecasts based on a cross-sectional model, which only requires firms' fundamental features such as accounting numbers, have emerged as an alternative method (Hou, van Dijk, \& Zhang, 2012: hereafter HVZ). This method is widely applied to exploring the mean reversion characteristics of earnings (Fama \& French, 2000), estimating the implied cost of capital (HVZ; Li \& Mohanram, 2014), detecting market overreactions to analyst forecasts (So, 2013), and improving forecasts in connection with the differential persistence of earnings components (Call, Hewitt, Shevlin, \& Yohn, 2016) or past analyst forecasts (Azevedo, Bielstein, \& Gerhart, 2020).

Earnings forecasts from a cross-sectional model (hereafter "model forecasts") have two outstanding benefits. First, model forecasts enable 
us to obtain forecast numbers for any firm as long as the basic accounting numbers are available (HVZ). As is known, both the number of firms covered by analysts and the length of the forecasting period are severely limited. Management forecasts are published frequently, especially in Japan, but the forecasting period does not exceed one year. On the other hand, model forecasts, which are available over several years, would enhance the completeness of the sample.

Second, model forecasts are relatively immune to the bias that is inextricably involved in analyst and management forecasts (Fama \& French, 2000; HVZ). Unless the accounting numbers introduced into the model have a systematic correlation with unobservable factors, such as manager's personal incentives, model forecasts provide unbiased estimates of future earnings (So, 2013). It is certain that analyst forecasts and management forecasts incorporate rich information, as they possess much private information. However, the presence of bias, which severely undermines the benefits of such forecasts, sheds light on model forecasts as an alternative source of information for market participants.

However, it is unclear whether market participants unconditionally prefer model forecasts as a market expectation of earnings. As long as alternative types of forecasts, such as analyst and management forecasts, compete in the market, each forecast has its own benefits and limitations (Brown \& Rozeff, 1978). Identifying the condition, under which model forecasts produce better outcomes for market participants, helps them distinguish the competitive forecasts successfully. This study attempted to elucidate the conditions under which model forecasts work well adds new insights to the research into the usefulness of accounting information.

To do so, this study relied on a measure of earnings quality suggested by Dechow and Dichev (2002) (hereafter DD). In their argument, the extent to which operating cash flows are properly mapped to short-term accruals captures the magnitude of measurement errors in such accruals. Market participants recognize the low quality of the DD measure as one of the risks (Francis, LaFond, Olsson, \& Schipper, 2005; Kravet \& Shevlin, 2010; Ogneva, 2012), or at least a proxy affecting other types of risks such as market beta (Core, Guay, \& Verdi, 2008). In fact, earnings quality is known to have a systematic effect on stock returns and is negatively correlated with 
the implied cost of capital, which is reverse engineered from stock prices (Francis, LaFond, Olsson, \& Schipper, 2004).

The cross-sectional model for earnings forecast includes historical earnings data as an explanatory variable. Depending on earnings numbers with large measurement errors would not produce accurate forecasts. As DD demonstrate, earnings quality has a significant correlation with the magnitude of business uncertainty, such as the length of the operating cycle and sales fluctuations. In addition, it is intuitive to infer that it is relatively difficult to forecast earnings of those firms surrounded by an extremely uncertain environment (Das, Levine, \& Sivaramakrishnan, 1998; Donelson $\&$ Resutek, 2015). Based on such arguments, this study empirically shows that higher earnings quality, as measured by the DD metric, leads to smaller forecasting errors.

In terms of the one-period-ahead forecast, firms in the top quintile of earnings quality experience less opportunistic bias, as measured by $10.4 \%$ of market capitalization, compared to firms in the lowest quintile. It is also evident from the result that moving from the bottom to the top quintile, the accuracy, measured by the absolute value of bias, improves by as much as $20.0 \%$ of the market capitalization, on average. Controlling for alternative earnings attributes does not change the tenor of the findings. An improvement in earnings quality by 1 percentage point not only reduces the bias by $0.95-0.98$ percentage points but suppresses the absolute forecast error by 1.26-2.07 percentage points. Furthermore, after removing the look-ahead bias pertinent to estimating earnings quality, the DD metric still serves as a benchmark for assessing the usefulness of model forecasts.

\section{LITERATURE REVIEW}

This study contributes to two streams of research. First, previous research on the accuracy of earnings forecasts has argued that analyst and management forecasts are constrained by biases stemming from economic incentives (Francis \& Philbrick, 1993; Lin \& McNichols, 1998; Aboody \& Kasznik, 2000; Rogers \& Stocken, 2005; Chan et al., 2018) or overconfidence (Hilary et al., 2016; Hribar \& Yang, 2016). However, the absence of such incentives or cognitive issues does not guarantee that earnings forecasts are free from 
biases. This study shows that the bias remains even if future earnings are forecasted by means of a firm's fundamentals alone, and that the magnitude of bias covariates with earnings quality.

Second, the role of DD's earnings quality metric has been tested primarily in terms of its effect on market-based indicators such as the cost of capital and the cost of debt (Francis et al., 2004; 2005; Kravet \& Shevlin, 2010; Ogneva, 2012; Du \& Jiang, 2020). This study suggests that this earnings quality metric is also closely associated with the accuracy of earnings forecasts. The difficulty in processing information due to uncertainty is known to confuse earnings forecasts by analysts and management (Das et al., 1998; Gong, Li, \& Xie, 2009; Donelson \& Resutek, 2015). Consequently, earnings quality is expected to affect the outcome of model forecasts as long as it partially reflects the complexity of the firm's business conditions (DD).

\section{RESEARCH DESIGN}

\section{Cross-sectional Forecasting Model}

Model forecasts are derived by estimating the following equation (1), which is proposed by HVZ, across sample firms over the past 10 years, including the forecasting period, and then applying the obtained coefficients to the explanatory variables in equation (1) of the forecasting period.

$$
E_{i, t+\tau}=\alpha_{0}+\alpha_{t} A_{i, t}+\alpha_{2} D_{i, t}+\alpha_{3} D P_{i, t}+\alpha_{4} E_{i, t}+\alpha_{5} \operatorname{Neg} E_{i, t}+\alpha_{6} A C_{i, t}+\varepsilon_{i, t+\tau},
$$

where $E_{i, t+\tau}$ is the net income of firm $i$ in year $t+\tau(\tau=1$ to 5$), A_{i, t}$ is the total assets, $D_{i, t}$ is the dividend payment, $D P_{i, t}$ is a dummy variable that takes 1 (0) when paying (not paying) dividends in year t, $N e g E_{i, t}$ is a dummy variable that takes $1(0)$ for firms with negative (positive) earnings, and $A C_{i, t}$ is the accruals.

Note that $A C$ (for simplicity, subscripts are omitted) is calculated through the balance sheet approach, i.e., $A C=\triangle C A-\triangle C L-\triangle C A S H+$ 
$\triangle S T D E B T-\triangle L T A L L O W-D E P N$ where $\triangle C A$ is the change in current assets, $\triangle C L$ is the change in current liabilities, $\triangle C A S H$ is the change in cash and cash equivalent, $\triangle S T D E B T$ is the change in short-term debt, $\triangle L T A L L O W$ is the change in long-term allowance, and $D E P N$ is the depreciation and amortization expense. To deal with the effect of outliers, all the level variables are winsorized at $1 \%$ and $99 \%$ levels for each year.

Bias and accuracy are derived by comparing the forecasted earnings for one to five periods ahead, calculated as the fitted values of equation (1), with realized earnings. $B I A S_{+\tau}$ obtained by subtracting the model forecasts for year $\tau$ from the realized earnings and scaling the difference by the market capitalization at the forecasting period ( $\tau=1$ to 5). A negative (positive) implies that the model forecasts are optimistic (pessimistic), because the model forecasts are larger (smaller) than the actual earnings. On the other hand, $A B S F E_{+\tau}$, which represents the accuracy of model forecasts, is defined as the absolute value of $B I A S_{+\tau}$, and a smaller $A B S F E_{+\tau}$ means that the forecasted values are closer (accurate) to the actual values.

\section{Earnings Quality Metric and Other Attributes}

Following Francis et al. (2005), the measure of earnings quality is given by the standard deviation of the residuals estimated in the crosssectional version of DD's regression model (2).

$$
\Delta W C_{i, t} / \bar{A}_{i, t}=\beta_{0}+\beta_{1} C F O_{i, t-1} / \bar{A}_{i, t}+\beta_{2} C F O_{i, t-1} / \bar{A}_{i, t}+\beta_{3} C F O_{i, t-1} / \bar{A}_{i, t}+\epsilon_{i, t}
$$

where $\triangle W C / \bar{A}$ is the change in working capital $(\triangle W C=\triangle C A-\triangle C L$ - $\triangle C A S H+\triangle S T D E B T)$ standardized by the average total assets $A$, and $C F O / A$ is cash flows from operation $(C F O=E-A C)$ scaled by the average total assets. Again, each variable for upper and lower $1 \%$ observations is winsorized for each year. Taking the standard deviation of the residual $\epsilon$, obtained from equation (2) over the past five years, including the forecasting period, earnings quality metric, SRESID, which is the variable of interest is derived.

In addition to SRESID, the other attributes of earnings that could affect the bias and accuracy of the model forecasts should be addressed. Based on prior research, several characteristics other than SRESID that 
potentially affect the performance of model forecasts are discussed. Detailed construction of these variables is presented in the Appendix. First, the smoothed earnings eliminate transitory fluctuations in the firm's performance, reflecting manager's long-term perspectives (Dechow, 1994; Francis et al., 2004). The degree of smoothness, denoted as SMOOTH, hence contributes to signaling more representative earnings numbers. In the context of earnings forecast, SMOOTH is desirable as it makes future earnings less difficult to predict.

Second, discretionary accruals are sometimes arbitrarily used to boost manager's perquisite (eg., Bergstresser \& Philipon, 2006), and do not appear to reflect the firm's long-term business conditions. As Dechow, Sloan, and Sweeney (1995) argue, discretionary accruals represent the measurement error in that they deviate from the "normal" part of accruals that are generated according to the level of the firm's business activities (Dechow, Ge, \& Schrand, 2010), which leads to the inference that discretionary accruals will be of less use in forecasting future earnings. As such, the standard deviation of discretionary accruals over the past five years is added as another explanatory variable $(D A C)$.

Third, persistence (PERSIST), which is measured by the first-order autoregressive coefficient of earnings, has also attracted attention as an indicator that describes earnings dynamics over time (Freeman, Ohlson, \& Penman, 1982). In particular, the expected growth in payoffs after the forecasting period has a sharp effect on the accuracy of the terminal value calculation (Penman \& Sougiannis, 1998) and assessing persistence is one of the most important ingredients of valuation. Given the fact that competition among firms facilitates mean reversion in profitability (Fama \& French, 2000), highly persistent earnings represent greater sustainability and have advantages in forecasting future earnings corresponding to the competitive environment in which the firm operates.

Fourth, since earnings consist of two components, i.e., cash flows from operation and accruals, persistence can also be decomposed into two corresponding parts. In general, accruals tend to be less persistent than operating cash flows, as the measurement errors contained in the accruals weaken the connection between accruals and future cash flows (Sloan, 1996). The downward bias associated with the persistence of accruals compared 
to that of cash flows signifies the degree of such measurement errors. The greater the magnitude of these measurement errors, the less useful accruals are in forecasting future earnings. Therefore, this study adopts the difference between the persistence of operating cash flows and the persistence of accruals (DIFFPER) as an additional explanatory variable.

In addition to the aforementioned variables, this study controls for the impact of firm size and growth on earnings forecasts. Capital market research presents cumulative evidence that larger firms (Chaney \& Jeter, 1992; Collins, Kothari, \& Rayburn, 1987) and higher growth firms (Warfield, Wild, \& Wild, 1995) are more likely to disclose useful information to the market. Since the forecasting method of HVZ (i.e., equation (1)) contains accounting numbers as generic inputs, these firm characteristics may well affect the performance of model forecasts. Hence, this study included the variables representing size (SIZE) and growth $(M / B)$ of the firm, where SIZE is defined as the natural logarithm of total assets, and $M / B$ is defined as the natural logarithm of the ratio of market equity to book equity.

As highlighted by Francis et al. (2004), the standard deviation of earnings is closely related to both SRESID and SMOOTH. Intuitively, earnings variability adversely affects the performance of the model forecasts. Hence, the standard deviation of earnings standardized by average assets over the previous five years $(S T D E)$ was chosen as the last explanatory variable. In multivariate regression analysis in the later section, the standard deviations of the explanatory variables other than dummy variables (STDA for total assets, $S T D D I V$ for dividends, and $S T D A C$ for accruals) were also taken into account.

\section{SAMPLE SELECTION AND DESCRIPTIVE STATISTICS}

The sample consisted of all firms listed on the Tokyo Stock Exchange, for which consolidated financial statement data and stock prices for 1985-2017 are available from the Nikkei NEEDS FinancialQUEST database. Because the past 10 years' data are required to estimate the cross-sectional model (i.e., equation (1)), the effect of earnings quality on bias and accuracy of the model forecasts was investigated for the period of 1995-2017. Financial firms (banks, securities, and insurance) and observations that lack the 
variables required to derive earnings quality and model forecasts were excluded. The final sample, with all earnings forecasts up to five years in the future and earnings quality, consisted of 35,722 firm-year observations.

Table 1: Descriptive Statistics

\begin{tabular}{|c|c|c|c|c|c|c|c|c|}
\hline & $\#$ Obs. & Mean & Std. Dev. & $1 \%$ & $25 \%$ & Median & $75 \%$ & $99 \%$ \\
\hline \multicolumn{9}{|c|}{ Earnings Quality } \\
\hline SRESID & 35,722 & 0.023 & 0.018 & 0.004 & 0.011 & 0.018 & 0.028 & 0.094 \\
\hline$W C / \bar{A}$ & 35,722 & 0.001 & 0.057 & -0.159 & -0.020 & 0.002 & 0.024 & 0.150 \\
\hline$C F O_{-1} / \bar{A}$ & 35,722 & 0.059 & 0.082 & -0.129 & 0.026 & 0.057 & 0.091 & 0.253 \\
\hline $\mathrm{CFO}_{0} / \bar{A}$ & 35,722 & 0.061 & 0.074 & -0.124 & 0.028 & 0.060 & 0.094 & 0.253 \\
\hline $\mathrm{CFO}_{+1} / \bar{A}$ & 35,722 & 0.063 & 0.080 & -0.130 & 0.029 & 0.061 & 0.097 & 0.262 \\
\hline \multicolumn{9}{|c|}{ Cross-sectional Forecasting Model } \\
\hline$F E_{+1}$ & 35,706 & 0.109 & 1.666 & -0.282 & 0.031 & 0.054 & 0.090 & 0.820 \\
\hline$F E_{+2}$ & 35,706 & 0.134 & 1.928 & -0.167 & 0.033 & 0.058 & 0.107 & 0.794 \\
\hline$B I A S_{+1}$ & 33,053 & -0.052 & 1.333 & -1.121 & -0.034 & 0.003 & 0.030 & 0.420 \\
\hline$B I A S_{+2}$ & 30,505 & -0.060 & 1.426 & -1.012 & -0.053 & -0.001 & 0.037 & 0.448 \\
\hline$A B S F E_{+1}$ & 33,053 & 0.130 & 1.328 & 0.001 & 0.013 & 0.031 & 0.081 & 1.290 \\
\hline$A B S F E_{+2}$ & 30,505 & 0.146 & 1.420 & 0.001 & 0.018 & 0.044 & 0.103 & 1.185 \\
\hline$E^{\mathrm{a}}$ & 35,722 & 6,723 & 47,916 & $-20,610$ & 191 & 940 & 3,590 & 126,653 \\
\hline$A^{\mathrm{a}}$ & 35,722 & 331,620 & $1,341,699$ & 2,627 & 21,037 & 51,625 & 158,597 & $5,436,175$ \\
\hline$D I V$ & 35,722 & 2,404 & 12,623 & 0.00 & 99 & 325 & 1,120 & 36,686 \\
\hline$D P$ & 35,722 & 0.89 & 0.31 & 0.00 & 1.00 & 1.00 & 1.00 & 1.00 \\
\hline$N e g E$ & 35,722 & 0.16 & 0.37 & 0.00 & 0.00 & 0.00 & 0.00 & 1.00 \\
\hline$A C^{\mathrm{a}}$ & 35,722 & $-13,774$ & 93,313 & $-281,902$ & $-5,209$ & $-1,203$ & -101 & 25,983 \\
\hline \multicolumn{9}{|c|}{ Control Variables } \\
\hline SMOOTH & 24,986 & 0.600 & 0.609 & 0.039 & 0.234 & 0.430 & 0.766 & 2.839 \\
\hline$D A C$ & 24,986 & 0.041 & 0.028 & 0.007 & 0.022 & 0.033 & 0.051 & 0.142 \\
\hline DIFFPER & 24,986 & -0.005 & 0.294 & -0.868 & -0.125 & -0.004 & 0.114 & 0.849 \\
\hline PERSIST & 24,986 & 0.300 & 0.402 & -0.512 & 0.035 & 0.290 & 0.541 & 1.292 \\
\hline STDE & 24,986 & 0.084 & 0.148 & 0.004 & 0.017 & 0.035 & 0.085 & 0.658 \\
\hline$M / B$ & 24,958 & -0.064 & 0.659 & -1.400 & -0.504 & -0.105 & 0.337 & 1.677 \\
\hline SIZE & 24,986 & 11.277 & 1.587 & 8.164 & 10.181 & 11.076 & 12.189 & 15.611 \\
\hline
\end{tabular}

a. These variables are measured in $¥$ millions.

Table 1 reveals the descriptive statistics of the main variables required for the empirical tests. First, with respect to the earnings quality metric (SRESID), mean values of past, present, and future operating cash flows (scaled by the average total assets) $\mathrm{CFO}_{-1}, \mathrm{CFO}_{0}$, and $\mathrm{CFO}_{+1}$ and are $0.059,0.061$, and 0.063 , respectively, which were lower than the average operating cash flow reported in DD (i.e., 0.075). The mean and standard deviation of the change in working capital $(\Delta W C)$ are 0.001, and 0.057, respectively, both of which were smaller than those reported in DD (0.015 and 0.070 ). The resulting earnings quality variable (SRESID) had a mean of 0.023 and a median of 0.018 , showing a distribution similar to that of DD (0.028 and 0.020). 
Turning to the model forecasts, the distribution of explanatory variables for the cross-sectional model had somewhat different characteristics from those of HVZ. The coefficients of variation of the variables used in this study (HVZ) were, 7.13 (3.77) for earnings $(E), 4.05$ (3.60) for total assets $(A), 5.25$ (3.63) for dividend $(D)$, and $-6.77(-3.65)$ for accruals $(A C)$, respectively. In short, the basic accounting numbers of the Japanese listed firms are more volatile than those of the US counterpart. The proportion of firms paying dividends $(D P)$ seemed to be higher in Japan ( 0.89 , on average) than in the US ( 0.49 on average). Conversely, the proportion of firms reporting negative earnings $(\mathrm{NegE})$ was lower for Japanese firms $(0.16$, on average) than for US firms $(0.25$, on average).

Despite these differences, the mean (median) bias of the one-yearahead model forecasts $\left(B I A S_{+1}\right)$ is $-0.052(0.003)$, which was comparable to the mean (median) bias reported by HVZ, -0.021 (0.003). The mean (median) value of the accuracy $\left(A B S F E_{+1}\right)$ was $0.130(0.031)$, larger than (equivalent to) the mean (median) accuracy of HVZ, 0.084 (0.030). The mean (median) absolute error of the two-period-ahead forecasts $\left(A B S F E_{+2}\right)$, $0.146(0.044)$, was greater than that of the one-period-ahead forecasts, which is consistent with HVZ. Hence, there were no significant discrepancies between this study and previous research regarding the distributional characteristics of the main variables.

\section{RESULTS}

\section{Univariate Analysis}

Table 2 reports the mean values of $B I A S_{+1}$ and $A B S F E_{+1}$ for each quintile based on the ranked size of SRESID. The best earnings quality firms (smallest SRESID group, Q1) had a mean bias of -0.009, while the worst earnings quality firms (largest SRESID group, Q5) had a mean bias of -0.113, where the increase in $B I A S_{+1}$ across the quintiles was monotonic. As earnings quality declined, the bias consistently increased. The difference between the top and bottom quintiles (Q5-Q1), -0.104, was statistically significant at the $1 \%$ level, indicating the possibility that the lower the earnings quality, the more optimistic outcomes the cross-sectional forecasting model is likely to yield. 
This relationship was also evident in the proportion of firms, whose mean $B I A S_{+1}$ was negative in each group. Table 2 reports that, in the highest earnings quality quintile, Q1, optimistic forecasts accounted for $47 \%$ of the sample therein, but as earnings quality declined, this percentage increased monotonically. In Q5, which exhibited the lowest earnings quality, the percentage of negative $B I A S_{+I}$ reached $52 \%$, suggesting that the optimistic forecasts become dominant. Hence, it can be confirmed that the low quality of earnings, characterized by a sparse association with cash flows, causes the model forecasts to be overestimated. The proportion of negative $B I A S_{+1}$ provides additional evidence that SRESID influences the bias of model forecasts.

Table 2: Mean Values of Bias and Accuracy by Earnings Quality Quintile

\begin{tabular}{|c|c|c|c|c|c|c|}
\hline & $Q 1$ & $Q 2$ & $Q 3$ & $Q 4$ & $Q 5$ & $Q 5-Q 1$ \\
\hline \multicolumn{7}{|l|}{$B I A S_{+1}$} \\
\hline Mean & -0.009 & -0.026 & -0.033 & -0.081 & -0.113 & -0.104 \\
\hline p-val. & & 0.02 & 0.20 & 0.05 & 0.38 & 0.00 \\
\hline$\%$ of negative values & 46.89 & 48.39 & 49.16 & 49.75 & 52.09 & 5.20 \\
\hline \multicolumn{7}{|l|}{$A B S F E_{+1}$} \\
\hline Mean & 0.063 & 0.079 & 0.088 & 0.157 & 0.263 & 0.200 \\
\hline p-val. & & 0.03 & 0.09 & 0.00 & 0.00 & 0.00 \\
\hline
\end{tabular}

This finding reinforces the results of previous research (eg., Lin \& McNichols, 1998; Rogers \& Stocken, 2005), who report that analyst and management forecasts tend to overestimate one-period-ahead earnings. As confirmed in Table 1, the mean value of was negative (-0.052), which indicated that the model forecast is also subject to an opportunistic bias. In light of this fact, even if there is no incentive for analysts and managers to intentionally disclose optimistic forecasts, low quality of realized earnings, on which they rely in forming next-period forecasts, could inevitably trigger off overestimation bias.

Furthermore, Table 2 presents the relationship between SRESID and the accuracy measure, $A B S F E_{+1}$, of one-period-ahead model forecasts, based on the quintile of SRESID. The mean value of $A B S F E_{+1}$ in Q1, which had the highest earnings quality, was 0.063 , and consistently evolved to 0.263 in Q5. The differences in mean values between each adjacent quantile were all statistically significant, and the difference of 0.200 between Q5 and Q1 was also significant at the $1 \%$ level. Again, it is confirmed that earnings quality enhances the accuracy of model forecasts. Collectively, the results 
of univariate analysis with respect to bias and accuracy indicated that the earnings quality is one of the leading factors influencing the effectiveness of earnings forecasts using the cross-sectional model.

\section{Multivariate Analysis}

The analysis thus far did not consider various factors that affect the forecast errors other than SRESID, and the results presented above may therefore be overestimated. Among those factors, this study selected four attributes related to actual earnings, i.e., SMOOTH, DAC, DIFFPER and PERSIST. To control for the effects of size and growth potential, SIZE and $M / B$ were incorporated as additional variables. Finally, STDE was considered as a proxy for the intrinsic difficulty of earnings forecast.

Table 3: Forecast Errors, Earnings Quality, and Other Earnings Attributes Panel A: The Effect of SRESID on BIAS

\begin{tabular}{|c|c|c|c|c|c|c|}
\hline & (1) & (2) & (3) & (1) & (2) & (3) \\
\hline Const. & $-0.164 * * *$ & $-0.156^{* * *}$ & $-0.157 * * *$ & $0.158 * * *$ & $0.113^{* * * *}$ & $0.127 * * *$ \\
\hline $\mathrm{t}$-val. & -6.55 & -5.66 & -5.62 & 6.59 & 4.34 & 4.95 \\
\hline SRESID & $-1.113^{* * *}$ & $-0.947 * *$ & $-0.975^{* *}$ & $2.822 * * *$ & $2.065^{* * *}$ & $1.264 * * *$ \\
\hline $\mathrm{t}$-val. & -2.96 & -2.48 & -2.33 & 8.22 & 5.79 & 3.19 \\
\hline SMOOTH & & $-0.010 * *$ & $-0.012 *$ & & $0.039^{* * *}$ & $0.013 * *$ \\
\hline $\mathrm{t}$-val. & & -2.40 & -1.95 & & 9.34 & 2.27 \\
\hline$D A C$ & & -0.071 & 0.060 & & $0.530 * * *$ & -0.109 \\
\hline t-val. & & -0.51 & 0.24 & & 4.19 & -0.46 \\
\hline DIFFPER & & $-0.013^{*}$ & $-0.014 *$ & & $0.016^{* *}$ & 0.010 \\
\hline t-val. & & -1.75 & -1.80 & & 2.26 & 1.46 \\
\hline PERSIST & & $0.010^{*}$ & 0.009 & & -0.005 & $0.008^{*}$ \\
\hline $\mathrm{t}$-val. & & 1.81 & 1.64 & & -1.00 & 1.74 \\
\hline STDE & & & 0.064 & & & $0.263 * * *$ \\
\hline $\mathrm{t}$-val. & & & 1.11 & & & 4.95 \\
\hline STDA & & & $-0.010^{*}$ & & & $0.011^{*}$ \\
\hline $\mathrm{t}$-val. & & & -1.71 & & & 1.92 \\
\hline$S T D D I V$ & & & 0.322 & & & -0.945 \\
\hline $\mathrm{t}$-val. & & & 0.37 & & & -1.18 \\
\hline$S T D A C$ & & & -0.034 & & & $0.115^{*}$ \\
\hline $\mathrm{t}$-val. & & & -0.46 & & & 1.65 \\
\hline$M / B$ & $0.045^{* * *}$ & $0.044 * * *$ & $0.040 * * *$ & $-0.074 * * *$ & $-0.075^{* * *}$ & $-0.057 * * *$ \\
\hline t-val. & 5.51 & 5.37 & 4.34 & -9.76 & -9.68 & -6.54 \\
\hline SIZE & $0.014 * * *$ & $0.014 * * *$ & $0.014 * * *$ & $-0.012 * * *$ & $-0.010^{* * *}$ & $-0.011 * * *$ \\
\hline t-val. & 7.56 & 6.95 & 7.94 & -6.62 & -5.49 & -6.55 \\
\hline \#Obs. & 22,751 & 22,751 & 22,751 & 22,751 & 22,751 & 22,751 \\
\hline$R^{2}$ & 0.026 & 0.027 & 0.031 & 0.073 & 0.080 & 0.122 \\
\hline
\end{tabular}


This study conjectures that more smoothed earnings (smaller SMOOTH) makes it easier to forecast future earnings stream, so smaller $S M O O T H$ will facilitate the generation of a forecast that is relatively close to actual earnings. An analogous argument would hold when earnings are highly sustainable (PERSIST is large). Furthermore, when earnings are composed of accruals that are significantly less persistent than cash flows (DIFFPER is large), such earnings are of lower quality, and thus are expected to exacerbate the performance of model forecasts. On the other hand, since the discretionary accruals are subject to measurement error, the difficulty in earnings forecast is expected to increase in the proxy $D A C$. In addition, since the time-series fluctuation of earnings, $S T D E$, becomes a constraint for earnings forecast, it should have an adverse effect on the performance of the model forecasts.

Table 3 confirms that these inferences are generally valid for the sample. Panel A shows the results when the dependent variable is $B I A S_{+1}$. Controlling for only SIZE and $M / B$ (the first column), the coefficient on SRESID is -1.113, and the t-statistic is -2.96. Recall that the mean one-periodahead bias was negative (-0.052), as shown in Table 1. A lower earnings quality (larger SRESID) induces overestimated forecasts compared to the realized earnings, and therefore amplifies the degree of optimism embedded in the model forecasts. On the other hand, both SIZE (coefficient $=0.014$, $\mathrm{t}$-statistic $=7.56)$ and $M / B$ (coefficient $=0.045, \mathrm{t}$-statistic $=5.51)$ seem to suppress such optimism.

Controlling for the other earnings attributes does not alter this result. The second column of Panel A shows that the coefficient on SRESID is -0.947 (t-statistic $=-2.48$ ) given the effects of the four attributes, which was still significant at the $5 \%$ level. Turning to other aspects of earnings attributes, the coefficient on SMOOTH was -0.010 (t-statistic=-2.40), and more smoothed earnings ( $S M O O T H$ is smaller) suppresses the optimistic bias. This also applies to PERSIST (coefficient=0.010, t-statistic $=1.81$ ), and the optimistic bias of model forecasts was generally smaller for the firms with more persistent earnings (PERSIST is larger).

In contrast, the sign of the coefficient on $D A C$ was negative $(-0.071$, t-statistic $=-0.51)$, as expected, but not statistically significant. Since the coefficient on DIFFPER $(-0.013$, t-statistic=-1.75) was, significant at the 
$10 \%$ level, albeit marginally, the larger the difference in persistence between the components of earnings (DIFFPER is larger), the more optimistic the model forecasts. When the standard deviation of inputs for deriving the model forecasts, such as STDE (the third column) was included, the statistical significance of the above coefficients generally decreased, and the coefficient on PERSIST was now indifferent from zero. Nevertheless, the coefficient on SRESID $(-0.975$, t-statistic $=-2.33)$ was still significant at the $5 \%$ level, indicating that the effect of earnings quality on forecast bias is robust controlling other earnings attributes.

The role of earnings quality in reducing forecast errors is also evident in Panel B of Table 3, in which the dependent variable is $A B S F E_{+1}$. According to the first column, in which only the effects of SIZE and $M / B$ are considered, the coefficient on $\operatorname{SRESID}(2.822$, t-statistic $=8.22)$ is significant at the $1 \%$ level. This suggests that a 1 percentage point improvement in earnings quality reduces the forecast error by 2.8 percentage points, relative to market capitalization. Similar to the results of the univariate analysis shown in Table 2, lower earnings quality (larger SRESID ) is associated with lower accuracy, as measured by the absolute value of the forecast bias. It is confirmed that $A B S F E_{+1}$ is negatively associated with both SIZE (coefficients $=-0.012, \mathrm{t}$-statistic $=-6.62)$ and $M / B$ (coefficients $=-0.074$, t-statistic $=-9.76)$.

The importance of SRESID in explaining the variability of $A B S F E_{+1}$ manifested itself when compared to the coefficients estimated for the other earnings attributes, as shown in the second column. First, the coefficient on $S M O O T H$ was 0.039 (t-statistic $=9.34$ ), and was significant at the $1 \%$ level, indicating that more smoothed (smaller SMOOTH) earnings resulted in higher accuracy of the model forecasts. The coefficient on PERSIST was -0.005 (t-statistic $=-1.00$ ), and was not significant, while the coefficient on DIFFPER was 0.016 (t-statistic $=2.26$ ), and was significant at the $5 \%$ level, so the relative persistence of the accruals provided a clue to assess the accuracy of the model forecasts. Turning to the effect of $D A C$, the coefficient is $0.530(\mathrm{t}$-statistic $=4.19)$, suggesting a significant positive correlation with $A B S F E_{+1}$, as expected, but the economic significance was much smaller than SRESID. 
In fact, when the standard deviation of past earnings, $S T D E$, was included as an explanatory variable, earnings attributes except for SMOOTH (coefficient $=0.013, \mathrm{t}$-statistic $=2.27$ ) lost their statistical significance in explaining $A B S F E_{+}$. After controlling for the effect of $S T D E$ as well as other earnings attributes, the coefficient on $\operatorname{SRESID}(1.264$, t-statistic=3.19) decreased to a large extent (as much as 55\%), which is somewhat similar to the finding of Francis et al. (2004), although the dependent variable used by them is different from that used herein. In this vein, some of the earnings attributes affecting the accuracy of model forecasts can be replaced by $S T D E$. However, note that it is not appropriate to purge SRESID, which showed robustness to the control of different earnings attributes including $S T D E$, from the explanatory variables when considering the determinants of $A B S F E_{+1}$.

\section{ADDITIONAL TESTS}

\section{SRESID Based on A Time-series Model}

Additional tests were done to confirm whether the findings thus far were robust to several alternative specifications of SRESID, which is an indicator of earnings quality. First, following DD's method, this study estimated equation (2) using 8-year observations for each firm, and obtained firm-specific SRESID from the regression residuals. As Table 4 reports, when the sample firms were divided into quintiles of the ranked SRESID, which was derived from a time-series model, the basic insights remained unchanged. The result clearly suggested that as SRESID increases (i.e., earnings quality deteriorates), $B I A S_{+1}$ significantly decreased from -0.017 to -0.076 , while $A B S F E_{+1}$ increased from 0.057 to 0.197 .

Table 4: Earnings Quality Based on A Time-series Model and Forecast Error

\begin{tabular}{crrrrrr}
\hline & $Q 1$ & \multicolumn{2}{c}{$Q 2$} & \multicolumn{2}{c}{$Q 3$} & \multicolumn{2}{c}{$Q 4$} & \multicolumn{2}{c}{$Q 5-Q 1$} \\
\hline$B I A S_{+1}$ & & & & & & \\
Mean & -0.017 & -0.025 & -0.043 & -0.036 & -0.076 & -0.059 \\
p-val. & & 0.08 & 0.24 & 0.71 & 0.17 & 0.02 \\
$A B S F E_{+1}$ & & & & & & \\
Mean & 0.057 & 0.073 & 0.103 & 0.125 & 0.197 & 0.140 \\
p-val. & & 0.00 & 0.06 & 0.27 & 0.01 & 0.00 \\
\hline
\end{tabular}


Compared to Table 2, in which SRESID was calculated from a crosssectional regression model, the ability of SRESID to detect forecast errors declined for both $B I A S_{+1}$ and $A B S F E_{+1}$. In Table 4, the spreads of $B I A S_{+1}$ and $A B S F E_{+1}$ between Q1 and Q5 (Q5-Q1) were -0.059 (significant at the $5 \%$ level) and 0.140 (significant at the $1 \%$ level), respectively, whereas they were trivial relative to -0.104 (significant at the $1 \%$ level) for $B I A S_{+1}$ and 0.200 (significant at the $1 \%$ level) for $A B S F E_{+1}$, as reported in Table 2 . These patterns were also observed for 2-5-period-ahead model forecasts (untabulated). The results can be interpreted as showing the superiority of SRESID estimated from the cross-sectional regression model against SRESID based on the time-series model in assessing the performance of the model forecasts.

\section{The Effect of Look-ahead Bias}

One concern about equation (2) is that it included one-periodahead operating cash flows as an explanatory variable, which potentially introduced a look-ahead bias into the analysis. Such a bias may lead to finding results in favor of the inference made in this study. Hence, in order to avoid the look-ahead bias and arrange SRESID as a more practical measure to gauge earnings quality, this study excluded future operating cash flows from equation (2), and re-estimated SRESID from cross-sectional regression residuals. The mean (median) value of SRESID calculated in this way (untabulated) was 0.024 (0.019), which was almost the same as SRESID estimated with future operating cash flows (mean value is 0.023 , and median is 0.018 , respectively).

Table 5 shows the mean values of $B I A S_{+1}$ and $A B S F E_{+1}$ for the quintiles based on the ranked size of SRESID estimated without future operating cash flows, and the results are still consistent with the hypothesis. Moving from Q1 (best earnings quality) to Q5 (worst earnings quality), $B I A S_{+1}$ decreased by 10.8 percentage points, which means an increase in forecast optimism, while $A B S F E_{+1}$ increased by 19.5 percentage points, which means a deteriorated forecast accuracy. With respect to one-period-ahead model forecasts, removing one-period-ahead operating cash flows from the estimation of earnings quality did not have a considerable effect on the relationship between earnings quality and the performance of model forecasts. 
Table 5: Earnings Quality Estimated without Future Operating Cash Flows and Forecast Error

\begin{tabular}{crrrrrr}
\hline & $Q 1$ & \multicolumn{2}{c}{$Q 2$} & \multicolumn{1}{c}{$Q 3$} & \multicolumn{1}{c}{$Q 4$} & \multicolumn{1}{c}{$Q 5-Q 1$} \\
\hline BIAS +1 & & & & & & \\
Mean & -0.015 & -0.023 & -0.046 & -0.052 & -0.123 & -0.108 \\
p-val. & & 0.23 & 0.07 & 0.73 & 0.02 & 0.00 \\
$A B S F E_{+1}$ & & & & & & \\
Mean & 0.068 & 0.074 & 0.104 & 0.126 & 0.263 & 0.195 \\
p-val. & & 0.36 & 0.02 & 0.12 & 0.00 & 0.00 \\
\hline
\end{tabular}

\section{CONCLUSION}

Overall, the results of this study indicate that earnings quality has a remarkable impact on the performance of the model forecasts, for which reported earnings are a primary source of information. Even if there is no economic incentive to intentionally bias the earnings forecast, the quality of earnings, on which the model forecasts crucially depend, can be a key determinant of bias and accuracy of forecasted numbers. As long as alternative sources such as analyst forecasts and management forecasts are available, market participants can choose any information given the cost they have to bear. However, the finding of this study that earnings quality is positively associated with the performance of model forecasts provides them with an important insight in choosing among different types of earnings forecast.

\section{REFERENCES}

Aboody, D., \& Kasznik, R. (2000). CEO stock option awards and the timing of corporate voluntary disclosures. Journal of Accounting and Economics, 29(1), 73-100.

Azevedo, V., Bielstein, P., \& Gerhart, M. (2020). Earnings forecasts: The case for combining analysts' estimates with a cross-sectional model. Review of Quantitative Finance and Accounting. Forthcoming. 
Bergstresser, D., \& Philippon, T. (2006). CEO incentives and earnings management. Journal of Accounting and Economics, 80(3), 511-529.

Brown, L. D., \& Rozeff, M. S. (1978). The superiority of analyst forecasts as measure of expectations: Evidence from earnings. The Journal of Finance, 33(1), 1-16.

Call, A. C., Hewitt, M., Shevlin, T., \& Yohn, T. L. (2016). Firm-specific estimates of differential persistence and their incremental usefulness for forecasting and valuation. The Accounting Review, 91(3), 811-833.

Chan, J., Lin, S., Yu, Y., \& Zhao, W. (2018). Analysts' stock ownership and stock recommendations. Journal of Accounting and Economics, 66(2-3), 476-498.

Chaney, P. K., \& Jeter, D. C. (1992). The effect of size on the magnitude of long-window earnings response coefficients. Contemporary Accounting Research, 8(2), 540-560.

Collins, D. W., Kothari, S. P., \& Rayburn, J. D. (1987). Firm size and the information content of prices with respect to earnings. Journal of Accounting and Economics, 9(2), 111-138.

Core, J. E., Guay, W. R., \& Verdi, R. (2008). Is accruals quality a priced risk factor? Journal of Accounting and Economics, 46(1), 2-22.

Das, S., Levine, C. B., \& Sivaramakrishnan, K. (1998). Earnings predictability and bias in analysts' earnings forecasts. The Accounting Review, 73(2), 277-294.

Dechow, P. M. (1994). Accounting earnings and cash flows as a measure of firm performance: The role of accounting accruals. Journal of Accounting and Economics, 18(1), 3-42.

Dechow, P. M., \& Dichev, I. D. (2002). The quality of accruals and earnings: The role of accrual estimation errors. The Accounting Review, 77(Supplement), 35-59. 
Dechow, P. M., Ge, W., \& Schrand, C. (2010). Understanding earnings quality: A review of the proxies, their determinants and their consequences. Journal of Accounting and Economics, 50(2-3), 344-401.

Dechow, P. M., Sloan, R., \& Sweeney, A. P. (1995). Detecting earnings management. The Accounting Review, 70(2), 193-225.

Donelson, D. C., \& Resutek, R. J. (2015). The predictive qualities of earnings volatility and earnings uncertainty. Review of Accounting Studies, 20(1), 470-500.

Du, K., \& Jiang, X. D. (2020). Connections between the market pricing of accruals quality and accounting-based anomalies. The Accounting Review. Forthcoming.

Easton, P. D., \& Monahan, S. J. (2005). An evaluation of accounting-based measures of expected returns. The Accounting Review, 80(2), 501-538.

Fama, E. F., \& French, K. R. (2000). Forecasting profitability and earnings. Journal of Business, 73(2), 161-175.

Francis, J., \& Philbrick, D. (1993). Analysts' decisions as products of multitask environment. Journal of Accounting Research, 31(2), 216-230.

Francis, J., LaFond, R., Olsson, P. M., \& Schipper, K. (2004). Cost of equity and earnings attributes. The Accounting Review, 79(4), 967-1010.

Francis, J., LaFond, R., Olsson, P. M., \& Schipper, K. (2005). The market pricing of accruals quality. Journal of Accounting and Economics, 39(2), 295-327.

Frankel, R., \& Lee, C. M. C. (1998). Accounting valuation, market expectation, and cross-sectional stock returns. Journal of Accounting and Economics, 25(3), 283-319.

Freeman, R. N., Ohlson, J. A., \& Penman, S. H. (1982). Book rate-of-return and prediction of earnings changes: An empirical investigation. Journal of Accounting Research, 20(2), 639-653. 
Fried, D., \& Givoly, D. (1982). Financial analysts' forecasts of earnings: A better surrogate for market expectations. Journal of Accounting and Economics, 4(2), 85-107.

Gao, Z., Myers, J. N., Myers, L. A., \& Wu, W. (2019). Can a hybrid method improve equity valuation? An Empirical evaluation of the Ohlson and Johannesson (2016) model. The Accounting Review, 94(6), 227-252.

Gebhardt, W. R., Lee, C. M. C., \& Swaminathan, B. (2001). Towards an ex-ante cost of capital. Journal of Accounting Research, 39(1), 135-176.

Gong, G., Li, L. Y., \& Xie, H. (2009). The association between management earnings forecast errors and accruals. The Accounting Review, 84(2), 497-530.

Hilary, G., Hsu, C., Segal, B., \& Wang, R. (2016) The bright side of managerial over-optimism. Journal of Accounting and Economics, 62(1), 46-64.

Hou, K., van Dijk, M. A., \& Zhang, Y. (2012). The implied cost of capital: A new approach. Journal of Accounting and Economics, 53(3), 504-526.

Hribar, P., \& Yang, H. (2016). CEO overconfidence and management forecasting. Contemporary Accounting Research, 33(1), 204-227.

Kimbrough, M. D., Lee, H., \& Zheng, Y. (2020). Can managers be wrong and still be right? An examination of the future realization of current management forecast errors. The Accounting Review. Forthcoming.

Kravet, T., \& Shevlin, T. J. (2010). Accounting restatement and information risk. Review of Accounting Studies, 15(2), 264-294.

Li, K. K., \& Mohanram, P. (2014). Evaluating cross-sectional forecasting models for implied cost of capital. Review of Accounting Studies, 19(3), 1152-1185.

Lin, H., \& McNichols, M. F. (1998). Underwriting relationships, analysts' earnings forecasts and investment recommendations. Journal of Accounting and Economics, 25(1), 101-127. 
Lundholm, R., \& O'Keefe, T. (2001). Reconciling value estimates from the discounted cash flow model and the residual income model. Contemporary Accounting Research, 18(2), 311-335.

Ogneva, M. (2012). Accrual quality, realized returns, and expected returns: The importance of controlling for cash flow shocks. The Accounting Review, 87(4), 1415-1444.

Ohlson, J. A. (2001). Earnings, book values, and dividends in equity valuation: An empirical perspective. Contemporary Accounting Research, 18(1), 107-120.

Patell, J. (1976). Corporate forecasts of earnings per share and stock price behavior: Empirical tests. Journal of Accounting Research, 14(2), 246-276.

Penman, S. H., \& Sougiannis, T. (1998). A comparison of dividend, cash flow, and earnings approaches to equity valuation. Contemporary Accounting Research, 15(3), 343-383.

Pownall, G., Wasley, C., \& Waymire, G. (1993). The stock price effects of alternative types of management earnings forecasts. The Accounting Review, 68(4), 896-912.

Rogers, J. L., \& Stocken, P. C. (2005). Credibility of management forecasts. The Accounting Review, 80(4), 1233-1260.

Sloan, R. (1996). Do stock prices fully reflect information in accruals and cash flows about future earnings? The Accounting Review, 71(3), 289315.

So, E. (2013). A new approach to predicting analyst forecast errors: Do investors overweight analyst forecasts? Journal of Financial Economics, 108(3), 615-640.

Warfield, T. D., Wild, J. J., \& Wild, K. L. (1995). Managerial ownership, accounting choices, and informativeness of earnings. Journal of Accounting and Economics, 20(1), 61-91. 


\section{APPENDIX}

This Appendix shows the definition of control variables, i.e., earnings attributes other than SRESID, used in the multivariate regression model.

SMOOTH

$$
\text { SMOOTH }=\frac{S T D E}{S T D C A S H}
$$

where $S T D E$ is the standard deviation of $E / \bar{A}$ for the past five years including the forecasting period, STDCASH is the standard deviation of operating cash flows $(E-A C)$ scaled by $\bar{A}$ for the past five years including the forecasting period, $E$ is net income, $\bar{A}$ is the average total assets, and $A C$ is accruals. Note that accruals are calculated as $A C=\triangle C A-\triangle C L-$ $\triangle C A S H+\triangle S T D E B T-\triangle L T A L L O W-D E P N$, where $\triangle C A$ is the change in current assets, $\triangle C L$ is the change in current liabilities, $\triangle C A S H$ is the change in cash and cash equivalent, $\triangle S T D E B T$ is the change in short-term debt, $\triangle L T A L L O W$ is the change in long-term allowance, and $D E P N$ is the depreciation and amortization expense.

$D A C$

\section{$D A C=$ the standard deviation of discretionary accruals over the past five years including forecasting period}

Discretionary accruals are obtained by estimating the following equation in the cross-section, following the method of Dechow et al. (1995).

$$
\frac{A C}{\bar{A}}=\delta_{0}+\delta_{1}\left(\frac{1}{\bar{A}}\right)+\frac{\delta_{2}(R E V-\triangle A R)}{\bar{A}}+\delta_{3}\left(\frac{P P E}{\bar{A}}\right)+\eta,
$$

where $A C$ is accruals, $\bar{A}$ is the average total assets, $R E V$ is the sales revenue, $\triangle A R$ is the change in accounts receivable, and $P P E$ is the property, plant and equipment. The estimated regression residual $\eta$ corresponds to the discretionary part of accruals. 
PERSIST

PERSIST $=$ first order autoregressive coefficient of E,

where $E$ is net income. The magnitude of the coefficient $\lambda_{l}$ is defined as PERSIST from the following regression estimated individually using each firm's past 10 years' data including the forecasting period.

$$
\frac{E}{\bar{A}}=\lambda_{0}+\lambda_{1}\left(\frac{E_{-1}}{\bar{A}_{-1}}\right)+\xi,
$$

where $E\left(E_{-1}\right)$ is the (lagged) net income, $\bar{A}\left(\bar{A}_{-1}\right)$ is the (lagged) average total assets, and $\xi$ is the error term.

DIFFPER

$$
\begin{gathered}
\text { DIFFPER = the difference between the coefficients } \\
\text { from regressing earnings on lagged accruals } \\
\text { and lagged operating cash flows. }
\end{gathered}
$$

Specifically, based on Sloan (1996), the following regression model is estimated for each firm over the past ten years including current period, and the difference between the coefficients $\theta_{1}$ and $\theta_{2}$, i.e., $\theta_{2}-\theta_{1}$, is defined as DIFFPER.

$$
\frac{E}{\bar{A}}=\theta_{0}+\theta_{1}\left(\frac{A C_{-1}}{\bar{A}}\right)+\theta_{2}\left(\frac{C F_{-1}}{\bar{A}}\right)+\zeta,
$$

where $E$ is net income, $\bar{A}$ is the average total assets, $A C_{-I}$ is lagged accruals, $C F_{-1}$ is lagged operating cash flows $(E-A C)$, and $\xi$ is the error term. 